\title{
Mango Spraying Agreement as an Effort to Increase Mango Production to Support the Improvement of the People's Economy in Coastal Areas of Pekalongan Regency
}

\author{
Aminah \\ \{aminahlana@gmail.com\} \\ Diponegoro UniversityJl.Prof.H.Soedarto, S.H., Tembalang, Tembalang, Kota Semarang, Jawa Tengah \\ 50275 Indonesia
}

\begin{abstract}
In general, people planted mango trees for reforestation and did not take care of them because it was inefficient at both time and cost. That condition attracted capital owners' attention by leasing and profit-sharing transactions or called as "mango spraying agreement." This article analyzes such practice in Pekalongan Regency.The study used an empirical juridical approach and the specification of descriptive analysis. The study found that the mango spraying agreement is practiced in the form of lease and profit-sharing contracts should be made by oral agreement (without written documents), without witnesses, and within a period of once harvest. Moreover, the lessee paid the rent, maintained, protected, and entitled to collect them. The profit-sharing agreement was divided into the forms of maro and metal. The type of maro the contribution and the harvest were split into two, i.e., between the owner and the cultivator. On the other hand, the form of merely applied the profit-sharing between the owner, the capital owner, and the cultivator by the agreement, respectively. Then, the mango spraying agreement had provided benefits of increasing the production of mangos both in quality and quantity in Pekalongan regency. It ultimately had an impact on improving the community economy as the activity involved many parties in the community (owners, capital owners, sprayers, cultivators, shippers, and collectors) which particularly respectively obtained financial benefits and generally improved the economy of the coastal area's community in Pekalongan regency.
\end{abstract}

Keywords: Leasing, Mango Spraying Agreement, Pekalongan Regency

\section{INTRODUCTION}

Generally, mango trees in coastal areas are planted for reforestation purposes; many people leave the mango trees and do not take care of them for its inefficiency as it takes time and money. Mango is one of the commodities that possess economic and strategic value. This commodity also has sizeable market opportunities in both the domestic and export markets.[1]Mango is one of the essential horticultural cash crops. [2] They have to spare some of their time to fertilize and eradicate pests periodically; it is something that most people do not like. That condition attracts the attention of capital owners to tackle it by committing themselves to create agreements with the owners, in the form of lease and profit-sharing transactions (maro or metal), both types of the accords are then called as "mango spraying agreement." The agreement is commonly referred to by the people as the mango spraying.

The mango spraying agreement is unique in that it is different from the usual lease and profit-sharing contracts, as it happens in the coastal areas of northern Indonesia, precisely the District Provisions as referred to in Civil Code for the lease agreement and Law number 2 of 1960 concerning on the profit-sharing deal. This agreement involves various parties in the 
process; thereby, it gives financial benefits for the people involved in the coastal areas of Pekalongan regency.

This study aims at observing the process of the mango spraying agreement and the benefits of the contract in supporting the community economic development of the coastal areas in Pekalongan regency.

\section{Method}

The study used an empirical juridical approach that was a problem approach which not only reviewed and examined the legislation in force as the basis of the mango spraying agreement but also saw its implementation in the field. Then, it was found how the effect of the mango spraying agreement on the improvement of the community economy.

The specification was descriptive analysis in which its nature and purpose are to give a description or to describe the process of the mango spraying agreement and its correlation with the improvement of economic community development in the coastal areas of Pekalongan regency.

The data used in this study were primary data and secondary data. The primary data were obtained through direct research with respondents who were purposively selected, i.e., the mango trees owners, the lessee/the cultivators and the related stakeholders. The secondary data were obtained through documentation consisting of legal materials.

The research instruments used in the study were documentations through literature and field studies through observations and interviews.

The method of analysis chosen in the study was a qualitative analysis which was not only able to obtain a mere conclusion but also able applied in the development of other studies in the same field.

The result of the study was analyzed interpretatively using the theory of triadic law from Gustav Radbruchand the existing principles of the treaty law, and hereupon the conclusions were inductively drawn to answer the research problems.

\section{Findings}

The southern part of Pekalongan Regency is a highland, whereas the northern part is the lowland and some parts of it are coastal areas, namely Tirto, Wonokerto, Wiradesa, and Siwalan districts. Many mango trees grew in the coastal regions of Pekalongan Regency because those areas are suitable to grow mango trees as they have a strong summer season, low and medium rainfall volume, and optimum temperature from 24 to 27 degrees Celsius. According to Trivedi et al. reported that Mango (Mangifera indica L.) are the most popular tropical fruits in the Universe that belongs to the family of Anacardiaceae. It is known as the king of fruits. It is one of the essential fruit marketed in the world with global production exceeding 26 million tons in 2004[3].

Many mango trees grew in the yards of the residents' houses or government agencies and private offices which were initially intended for the reforestation. The reforestation with the mango trees mostly chosen by the people in the coastal areas not only because of the land and suitable climate but also because of their reasonably think branches with large leaves and as they were productive plants which produced fruits.According to Islam and Rahman that Climate change is one of the greatest threats to human lives and properties in the coastal region[4]. The reforestation with leafy mango trees also produced enough oxygen so that it 
could reduce the heat in the coastal areas of Pekalongan regency.

Some people let the mango trees grow without care. They left them alone without wondering whether or not the trees were fruitful, even if they were prolific, they did not care whether there were many or few of them. They did not care nor fertilize the mango trees by saying that they did not have time and considered it as a waste of time and cost.

The number of mango trees and omissions in the areas of the northern Pekalongan Regency had attracted the capital owners to tackle them by making the mango spraying agreement with the owners of the mango trees.

\subsection{The Process of the Mango Spray Agreement in the Coastal Areas of Pekalongan Regency}

The area in Pekalongan Regency which has yards with many mango trees on was Tirto District. Tirto District has 16 villages located in the lowland and the northern coastal area with suitable climate to grow the mango trees. Mangoes can be grown in almost every administrative district in the country, except parts of the central hilly regions. However, commercial cultivation is limited to areas below 600 masl, and they are grown mostly in dry zone areas[5]. Almost all villagers in Tirto District have mango trees in their yards, and they usually have more than one tree, most of which is arum manis type. Those who have large yards could have up to ten mango trees.

The mango trees are not only planted in the villagers' yards but also planted in the moor (a former rain-fed rice field) during the dry season, in the office or elementary schoolyards. According to Normand et al. Although mango tree is adapted to dry environments experiencing water stress and high evaporative demand, the expected increase of drought and vapor pressure deficit (VPD) would hurt photosynthesis because of the rapid stomatal closure of the mango tree when the climatic demand increase[6].Based on the result of the observation there were some moors planted with the mango trees around ten up to 100 trees, and there were some trees beside and behind the district office of Tirto, in the village office yard, and the elementary schoolyards.

In the beginning, the mango trees planted in the yards of the houses, the agency offices, elementary schools only aimed for reforestation, thus the cultivations were not intensively done, but they were just left alone so that their fruits were not too much and their quality was also reasonable. That condition attracted the capital owners who were also collectors and fruit sellers to rent. According to Gray and Haman For successful reforestation programs, planting stock must be both genetically well adapted to the target environment and contain a sufficient amount of genetic diversity. Generally, two decisions have to be made when selecting planting stock[7].

The lease agreement of the mango trees in the coastal areas of Pekalongan regency began to spread since 2010. The lease agreement of the mango trees was a unique legal relationship and different from the usual lease agreement whose object was the lessee's enjoyment over the object as outlined in Article 1548 and 1552 Civil Code, whereas the other lease agreement was a lease agreement with the right to harvest the mangos as the object.

The lease agreement as referred to in Article 1548 Civil Code should mean "an agreement, under which a party binds himself to confer onto another party the enjoyment over an object, for a definite period and for a price, which the latter agrees to pay. All kinds of objects, movable or immovable, may be rented".

The enjoyment of an object in the lease agreement as referred to in the Civil Code explicitly stated in Article 1552 Civil Code which read "the lessor is responsible to the lessee for all the defects of the leased property, which prevent the lessee's enjoyment of the property, 
even where such defects were unknown to the lessor at the conclusion of the agreement, if such defects cause damages to the lessee, the lessor must compensate for such damages."

If Article 1548 Civil Code was connected with Article 1552 Civil Code, then it is shown that the object of the usual lease agreement was the enjoyment of an object, either it was a movable or immovable object, this was what distinguishes the object on the lease agreement of the mango trees that was the right to harvest the trees.

The mango tree, when viewed from the type of the object, was included as an immovable object because of its character. According to Subekti[8], an object could be categorized as an immovable object ("ordered") firstly; because of its character, secondly; because of its usage purpose and third; because of the law. As for the objects which were categorized as immovable objects because of the character were land, including anything direct or indirect, because of nature or the human actions, combined tightly into one with the land. Thus, for example, a yard, along with what was in it and everything built therein permanently (a house) and planted therein (a tree), included the fruits that had not been harvested. The mango trees planted in the ground (yards or moors) meant that the trees were immovable objects.

The lease agreement of the mango trees in Pekalongan Regency generally had once harvest period with the average price for a tree around Rp 400,000 - Rp 500,000 for each harvest. The capital owner (the lessee) would give the rent money for once harvest; then the lessee would cover fertilization and spraying intensively before the harvest time arrived at the cost of the lessee. Generally, the propagation used chemical fertilizers, while the eradication of pests used pesticides. The closer it got to the harvest time, the more intense the spraying was done to eradicate the pests every day, the fertilization and the spraying were done in order to get many crops with good quality mangoes.

Not all of the mango trees were included in the system of the lease agreement, and sometimes they used the profit-sharing deal. The profit-sharing could be done with the operation of maro or metal. Maro meant parole (divided by two) which the crops would be divided into two, apart for the owner of the mango trees and another part for the party who had spent the cost covering the fertilization and the pest eradication (called spraying) to the mango trees. On the other hand, Metal meant that they were divided into three (tell) i.e. the crops would be divided into three which one third of them for the owner of the mango trees, another one third for the capital owner, and the rest one third for the party who had used his energy in making efforts to fertilize and eradicate the pests.

During the period of the lease agreement, Maro or Metelu the mango trees were generally dominated by the activity of spraying so that those three types of contract known as the mango spraying agreement, whereas the lessee or the cultivator and the one who do fertilization and eradication on the mango trees were called the sprayer.

Both the lease system and the profit-sharing system of maro and metalare usually called as the mango spraying agreement because in those three systems the spraying effort would be made periodically using pesticides and that activity seemed dominant and clear thus the term mango spraying became a popular term in the coastal areas of Pekalongan regency in general, and particularly in Tirto District of Pekalongan Regency.

The mango spraying agreement with the profit-sharing system of maro or metal when analyzed further was not a lease agreement, however, it was a cooperation agreement where the results would be divided because each party had done his share.

The mango spraying agreement had similarities and differences with the profit-sharing deal, as outlined in Law number 2 of 1960 on profit sharing. The profit-sharing agreement as referred to in Article 1 letter c shall mean an agreement that is held between the owners on the one hand and the person or the entity law on the other hands known as "tenants" under which 
arrangement the owner is allowed to carry out agricultural activities on the owner's land with the profit-sharing between the two parties.

The similarities were the immovable objects, however in the profit-sharing agreement as set forth in Law number 2 of 1960 the purpose was an agricultural land which had a particular area of the owner planted and worked by the tenants from the beginning of planting, maintenance until harvesting, whereas the objects of the mango spraying agreement with the profit-sharing system (maro or metal) were the mango trees which had grown and generally had ever bear fruits, the tenants/sprayers did not have to plant from the small size. He kept doing fertilizing and spraying pests until the harvest time arrived.

The differences were all profit-sharing agreements which were made by the owner, and the tenant as set forth in Law number 2 of 1962 should be done in written forms, should be made with the presence of the village officials or regional head equal to that in the location of the concerned land with two witnesses from each party of the owner and the cultivator, requiring the approval of the sub-district head, the area was determined not more than 3 hectares and with 3 years period of time for agricultural land and 5 years for dry land.Meanwhile, the mango spraying agreement was usually done orally, without any witness, without the presence of the village/regional head, without the acknowledgment of the sub-district head, without the restriction area because the mango spraying agreement was made not based on a particular area but based on the number of the trees with time limit only until the harvest time (usually lasted in September to October).

The mango spraying agreement was made orally because in general, the villagers in the coastal areas of Pekalongan Regency, especially in Tirto District trusted each other so that the formalities in the mango spraying agreement as outlined in Law number 2 of 1960 were no longer needed. The people living in Tirto District was a transitional society between the urban (modern) and the rural (traditional) areas, as it is located on the coast. Thus, besides influenced by the customs passed down by the ancestors, they were also influenced by the modern traditions. Therefore, the culture was also transitional. Then it affected the society's legal customs (its legal culture), especially in terms of agreeing.

In terms of making the agreements they sometimes used certain formalities which were required by the law while occasionally they did not use the ceremonies but only following the customs as in the land purchasing agreement since there were clear legal consequences that if the purchasing dealer was not done in the presence of the Land Deed Officer (PPAT), the land could not be certified, on the other hand sometimes they did not use certain formalities like the mango spraying agreement. Their reasons for not using the certain formalities were because they did not know the legal consequences, they said that the formalities were less practical, especially the mango spraying agreement did not include large amount and value. The mango spraying agreement only had one or more mango trees as the object and not more than 10 in every yard and in a short period that was only one harvest time because the mango trees are seasonal plants that produced fruits (usually not more than a year). It made the people felt safe even if the agreement was made orally and without the presence of the village head and witnesses because the mutual trust was the basis of the legal relationship of the mango spraying agreement.

The oral agreement did not mean that the agreement did not bind the parties, because the binding/the making of the agreement was only possible if a deal was made. One of the principles in the Civil Code applied the consensual principle, which determined that an agreement was considered to happen if the parties had reached a deal.

The first condition of the agreement as referred to in Article 1320 Civil Code shall have the meaning of the consensualprinciple, this principle was closely related to the law of 
freedom to contract as set forth in Article 1338 paragraph (1) Civil Code stated that "all legally executed agreements shall bind the individuals who have concluded them by law." The phrase "all agreements" was made to indicate the principle of freedom of contract, "shall bind as law" showed the policy of binding force (pactasuntnevada) "the individuals who have concluded them" showed the faith of personality. Thus, the agreement was born by the time the deal of the parties and the legally executed agreement bind and should be obeyed by who made it.

In the legally executed mango spraying agreement that had satisfied the four conditions as referred to in Article 1320 Civil Code namely 1) there must be consent of the individuals who are bound thereby; 2) there must be capacity to conclude an agreement; 3) there must be a specific subject; and 4) there must be an admissible cause which did not contrary to the law, morality, and public order, then due to the legally executed agreement was valid as law for the parties and should be obeyed. Based on that matter if it was analyzed further, actually there was no difference due to the law both the agreement made orally and in writing, if only it were made in writing would it have more legal certainty and could be used as evidence which was stronger than the oral one.

The mango spraying agreement was analyzed with Gustav Radbruch's theory of triadic law which was said to be the legal purpose of justice, certainty, and usefulness. The value of truth had a first and foremost position than the cost of legal benefit and assurance. The three of them were the fundamental constitutional values, and each value had different values so that all three were potentially conflicting and causing tension (spannungsverhatnis)[9]. Therefore, in the absence of the written mango spraying agreement indicated that the value of legal certainty was less important than the benefit value of the deal itself that was emphasized was the result of the deal that was very beneficial for both parties that the parties benefited materially that if the mango spraying agreement was in the form of a lease agreement, then the owner of the trees would get the rent fee and be given some mangoes as tasters, as for the lessee would be able to harvest the mango fruits which would be resold in order to gain profit, whereas if it were in the form of a profit-sharing agreement (maro or metal), each party would get a share in accordance with the original contract. Such mutual benefit could be felt like a balance in the consensus among the parties which meant that this had fulfilled the principle of stability in the agreement, with the existence of that balance it could be interpreted that the value of justice had been achieved.

\subsubsection{The Benefits of the Lease Agreement in Supporting the Improvement of Community Economic Development in the Coastal Areas of Pekalongan Regency}

The villagers popularly conducted the mango spraying agreement after 2010 in the coastal areas of Pekalongan regency, especially most of them in the Tirto district. The transaction involved several, among others, if it was in the form of a lease agreement, it meant the owner of the mango trees and the lessee, if it was in the form of profit-sharing, it involved the owner, the cultivator as well as the capital owner (in the maro system) or the preserver and the capital owner as different persons (in the metal system). Either the owner, the preserver (the sprayer) or the capital owner could come from the people of the coastal areas in Pekalongan regency.

The existence of the mango lease agreement (including the concept of the profit-sharing) motivates the community to plant the mango trees in their yards, the private institutions or the elementary schools which had yards planted the mango trees where could be found in the research location. There were a lot of good mangoes trees in the yards of the villagers, the 
private/government institutions, and the elementary schools.

The purposes of Saruman is mango trees planted in the yards initially only as a means of reforestation (before 2010), now (after 2010) they developed into an economic function that was a capital base which could generate financial benefits for either the owner, the sprayer or the capital owner.

For example, the benefit for the owner, if a yard had five mango trees and each mango tree was rented for Rp.500,000,-, then the owner of the mango trees could gain financial benefit for about Rp 2,500,000,- for one harvest, likewise on the maro or metal system. In the maro system, it meant that the owner would get half of it, in the metal system, the owner would get one-third of the crops/cash crop. If the harvest were not done during the harvest season, then the profit would be higher because the product price would soar, but if the harvest were done during the harvest season (September-October), the benefit would be lesser because the crops were abundant as the price would decrease.

From the side of the sprayer as well as the capital owner, he could sell his mangoes at the higher price than the cost capital needed, especially if the harvest were not done in the harvest season, then they would get an abundant profit. Moreover, the arumanis mangoes from Pekalongan were known for their excellent quality.

Besides the financial benefits the people involved in the mango spraying agreement also implied the existence of multiplayer effect on the parties that were outside the mango spraying agreement at the harvest time of the mangoes, with the existence of the mango harvest the cultivator, the basket owner, and the transport providers were needed and became rampant and they gain financial benefits, the cultivators could be hired, the basket owners could rent their baskets and the car owners could rent their cars as transportations from the harvest field to the collectors and Jakarta as the final marketing area of the mangoes from the Pekalongan regency.

The other implications appeared in the creative people who made diversification of mango products that the mangoes were not sold in the form of fresh fruits but the processed food such as mango jam, pudding, syrup, and chips. This creativity was initiated by the women from the family welfare movement (PKK) for the guidance of the related parties, also assistance provided by community service students (KKN) from universities who work in that area. Though the processed mango products in the community were still on a small scale, they were enough to give financial benefits.

The lease agreement of mangoes attracted the people's interest to plant mango trees in the yards so that the mango lease agreement could improve bothquality (developed into the profitsharing system) and quantity (more and more people made lease agreements of mangoes) aspect, that legal action was known as spraying mangoes. As the lease agreement increased, the mango production also increased and impacted the financial benefits increase for both the parties within and outside the agreement, which came all over from Pekalongan regency. Thus, it can be said that the lease agreement of mangoes supported the improvement of community economic development in the coastal areas of Pekalongan Regency.

\section{Conclusion}

From the research result and discussion above, it could be found that: The process of mango spraying agreement in the coastal areas of Pekalongan regency since 2014 was in the form of the lease agreement and profit-sharing agreement with verbal agreements (without written documents), without any witnesses, and within one harvest period. In the lease agreement form, the lessee paid the rent fee, treated, protect, and harvested the mangoes. In the profit-sharing form of maro, the contributions and crops were divided into 
two between the owners and the tenants, whereas in the profit-sharing form of metal they were divided by three that were between the owner, the capital owner, and the tenant by the agreement respectively.

The mango spraying agreement had given benefits that increased the production of the mangoes either in quality or quantity in Pekalongan regency. In the end, it affected the improvement of the community economic development, because the activity involved many parties in the community (owners, capital owners, sprayers, cultivators, shippers, and collectors) in which particularly each of them gained financial benefits. Moreover, generally, it improved the economic growth in the coastal areas of Pekalongan regency.

\section{References}

[1] S. A. Andayani, "Development Model of Mango Agribusiness As an Effort To Ensure Supply Continuity,” Sci. Pap. Manag. Econ. Eng. Agric. Rural Dev., vol. 17, no. 3, pp. 57-67, 2017.

[2] K. E. Banson and A. Egyir-Yawson, "Socio - Economic Impact of Fruit Flies Control in Mango Production in Ghana, Evidence from \&quot; Manya Krobo \&quot;", $J$. Agric. Sci. Technol. B J. Agric. Sci. Technol., vol. 4, no. October, pp. 454-463, 2014.

[3] M. Kumar Trivedi, "Morphological Characterization, Quality, Yield and DNA Fingerprinting of Biofield Energy Treated Alphonso Mango ('Mangifera indica' L.)," J. Food Nutr. Sci., vol. 3, no. 6, p. 245, 2015.

[4] S. A. Islam and M. M. Rahman, "Coastal afforestation in Bangladesh to combat climate change induced hazards," J. Sci. Technol. Environ. Informatics, vol. 02, no. 01, pp. 13-25, 2015.

[5] K. Peiris, "Government of the Democratic Socialist Republic of Sri Lanka," no. July 2016, pp. 90-91, 2018.

[6] F. Normand, P. Lauri, and J. M. Legave, "Climate change and its probable effects on mango production and cultivation," Acta Hortic., vol. 1075, no. March, pp. 21-32, 2015.

[7] L. K. Gray and A. Hamann, "Strategies for reforestation under uncertain future climates: Guidelines for Alberta, Canada," PLoS One, vol. 6, no. 8, 2011.

[8] Subekti, Pokok-Pokok Hukum Perdata, 31st ed. Jakarta: Intermasa, 2003.

[9] W. Handoko, Kebijakan Hukum Pertanahan Sebuah Refleksi Keadilan Hukum Progresif. Thafa Media, 2014. 